\title{
Pollenizer and Cultivar Influence Seed Number and Fruit Characteristics in Olea europaea L.
}

\author{
Daniela Farinelli ${ }^{1}$ \\ Dipartimento di Scienze Agrarie e Ambientali, Università degli Studi di \\ Perugia, Borgo XX Giugno, 74-06121 Perugia, Italy
}

Pierluigi Pierantozzi

Instituto Multidisciplinario de Biología Vegetal (IMBIV, CONICET-UNC), Instituto de Ciencia y Tecnología de los Alimentos (ICTA), Facultad de Ciencias Exactas, Físicas y Naturales (FCEFyNUNC), Av. Vélez Sarsfield 1611, X5016GCA Córdoba, Argentina

\author{
Assunta Maria Palese \\ Dipartimento di Scienze dei Sistemi Colturali, Forestali e dell'Ambiente, \\ Università degli Studi della Basilicata, Viale dell'Ateneo Lucano, 10-85100 \\ Potenza, Italy
}

Additional index words. crosses, undeveloped seed, double-seeded, seed pattern, seed death

Abstract. The effect of several pollination combinations of the olive cultivars Ascolan Tenera, Carolea, Leccino, and Picholine on seed quality and seed number and drupe and seed features were evaluated in 2007 and in 2008 in central Italy. The well-known pattern in olive fruit was confirmed by the high percentage of drupes $(71.8 \%$, on average) containing one seed with a closed endocarp, as the dispersal unit, optimizing the plant's investment in seedling survival. Based on the results of the $\chi^{2}$ test of independence, there was a significant maternal and paternal effect on the number of normal seeds per drupe in some years and combinations. Particularly, in 2007, Picholine and Leccino cultivars (as mother) had drupes with two normal seeds $(23.7 \%$ and $3.1 \%$, respectively, with respect to $10.8 \%$ observed in a normal seed pattern), confirming that double-seeding in olive could be cultivar-dependent. Also the specific crosspollination between 'Carolea', as a pollenizer, and 'Ascolana Tenera' gave rise to a higher proportion of double-seeded drupes in 2007 (39\% with respect to $14.3 \%$ expected to be in this category). In 2008 , although 'Ascolana Tenera' produced more drupes with undeveloped seeds $(31.9 \%$ with respect to $19.7 \%$ expected to be in that category), 'Leccino' and 'Carolea' had drupes with a lower number of undeveloped seed $(14.2 \%$ and $11.5 \%$, respectively). 'Maurino' and 'Ascolana Tenera' pollen produced significant effects on 'Leccino' drupes by increasing the number of drupes with undeveloped seeds in both experimental years. Double-seeded drupes outweighed those with only one normal seed in 'Leccino' and 'Picholine'. Instead, drupes with undeveloped seeds affected fruit weight, being generally lighter than those with normal seeds. Although the Leccino cultivar, combined with 'Maurino' and 'Ascolana Tenera', greatly increased the proportion of drupes without normal seed, such condition did not affect their final weight, which was not different from those with one normal seed, suggesting that this variety caused late seed death.

Fruit set assessment is currently the most commonly used method to test crosscompatibility among olive (Olea europaea L.) cultivars, thus identifying the best pollenizers (Androulakis and Loupassaki, 1990; Camposeo et al., 2012; Cuevas et al., 2001; Farinelli et al., 2002a, 2006, 2008a; FernandezEscobar and Gomez-Valledor, 1985; Guerin and Sedgley, 2007; Lavee, 1998; Lavee and Datt, 1978; Moutier, 2002; Rallo et al., 1990; Tombesi et al., 1982). To our knowledge,

Received for publication 30 May 2012. Accepted for publication 3 Aug. 2012.

${ }^{1}$ To whom reprint requests should be addressed; e-mail daniela.farinelli@unipg.it. olive flowers have four normal ovules, usually only one of them will be fertilized, giving origin to the seed. The fruit rarely contains two normal seeds (Cuevas et al., 1995), although there are some cultivars that may set fruit containing two normal seeds at a higher frequency (Cuevas and Oller, 2002), whereas others may not contain any seeds because of embryo death (Morettini, 1950; Rapoport and Rallo, 1990). It is important to note that the presence of a seed or seeds is very significant because the seed influences fruit development during the current year and the extent of flowering in the next annual olive cycle (Koubouris et al., 2010; Lavee, 2006; Rapoport, 1994).

In olive, like in other fruit, the number of seeds per fruit influences fruit and seed weight (Cuevas and Oller, 2002; Farinelli et al., 2002b; Stafford, 1970). Fruit containing two seeds is usually larger because of greater mesocarp and endocarp growth.

This aspect is very important in table olive cultivars, which must produce good-sized fruit with a high pulp/pit ratio. This is also important in olive oil cultivars because fruit with no normal seeds is smaller and contains less oil (Morettini, 1950). Furthermore, the absence of a normal seed in the fruit has an economic impact on propagation in olive nurseries, when reproduction methods are used to obtain seedlings destined for use as rootstocks for grafting. In fact, seed characteristics can affect germination and seedling quality. Also, competition among fruit is thought to be proportional to sink size, which in turn is related to fruit and seed mass, but not to fruit number (Farinelli et al., 2002b; Rosati et al., 2010).

In many fruit growth models such as the "Peach" model, sink strength is calculated taking into account the sink potential, which is proportional to fruit mass (Grossman and DeJong, 1994, 1995; Marcelis and Heuvelink, 1999). In olive, the percentage of fruit set, the percentage of undeveloped seed, and the number of drupes containing two seeds seem to be affected by the affinity between the cultivar and the pollenizer (Cuevas and Oller, 2002; Martin et al., 2005).

More in-depth studies on the relationship between cultivars and pollenizers in determining fruit set, embryo death, seed number, and development and fruit growth are needed as well as evaluation of the maternal and paternal influences.

In the present study, the effect of all possible pollination combinations among the cultivars Ascolana Tenera, Carolea, Leccino, and Picholine and other pollenizers on the number and quality of seeds and their development and drupe and seed characteristics was evaluated using the $\chi^{2}$ test of independence. 2002b, 2008b; Koubouris et al., 2010). Olive fruit is a drupe, consisting of the carpel, botanically similar to almond, apricot, cherry, nectarine, peach, and plum. The ovary wall has both fleshy and hard portions (Martin et al., 2005). A drupe usually contains a single seed enclosed by a hardened endocarp, which often adheres closely to the seed. Although

\section{Materials and Methods}

Self and cross treatments were applied to Ascolana Tenera, Carolea, Leccino, and Picholine cultivars to obtain drupes from a known pollen source according to the 


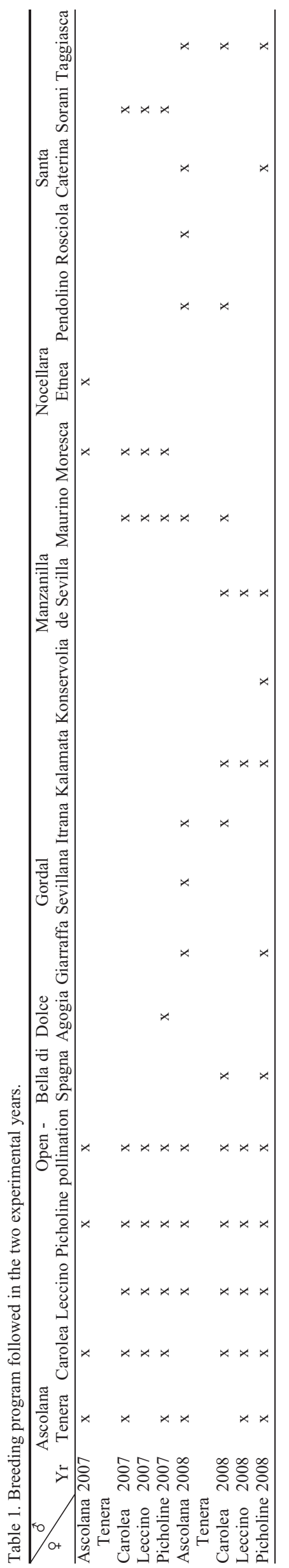

breeding program shown in Table 1 . The trial was carried out in 2007 and 2008 on 20 -year-old olive trees trained to the vase shape and planted at a $5 \times 5 \mathrm{~m}$ distance. Olive trees were cultivated at the University of Perugia experimental orchard (an olive germplasm bank) (lat. $43^{\circ} 04^{\prime} 54.58^{\prime \prime} \mathrm{N}$, long. $12^{\circ} 22^{\prime} 53.41^{\prime \prime} \mathrm{E}, 321 \mathrm{~m}$ a.s.1.) in central Italy. Four olive cultivars were used as mother plants: three of the main Italian cultivars (Ascolana Tenera, Carolea, and Leccino) and one French cultivar (Picholine). 'Ascolana Tenera' is cultivated for table use; 'Leccino' for oil purpose; and 'Carolea' and 'Picholine' are double-purpose cultivars. These four cultivars, and 16 others, were evaluated as pollenizers according to the selected crosses showed in Table 1 (Gordal Sevillana, Kalamata, Konservolia, Manzanilla de Sevilla, and Sorani as foreign cultivars; Bella di Spagna, Dolce Agogia, Giarraffa, Itrana, Maurino, Moresca, Nocellara Etnea, Pendolino, Rosciola, Santa Caterina, and Taggiasca among the most important Italian cultivars). The cultivar purposes are reported by Bartolini (2012). Each crossing treatment was applied on four to five branches per tree bearing 70 to 80 inflorescences each. The number of flower clusters on branches and the number of flowers per inflorescence were counted. Before bloom, self- and crosspollination treatments were performed by bagging the branches using white double-layer paper bags $(0.65 \times 0.35 \mathrm{~m})$ to prevent free pollination. For each cultivar, six to eight additional branches were used to determine the results of free pollination. This was ensured because in the experimental orchard, there were 80 cultivars that provided good conditions for free pollination (Ferrara et al., 2007). The stage of bloom of each variety was recorded every $2 \mathrm{~d}$. When $80 \%$ to $100 \%$ of the flowers of the cited cultivars bloomed, bags with pollen from the pollinator were transferred to the previously bagged branches of those trees selected to be artificially crosspollinated. Then, the bagged branches were hand-shaken several times to assure that the pollen would fall on the stigma. At the end of blooming, namely when the corolla was abscised, the paper bags were removed. The number of olives were counted $21 \mathrm{~d}$ after full bloom (80\% to $90 \%$ of the flowers bloomed) when the young fruit started to enlarge and when it was possible to distinguish them from those that were going to drop. Counting was repeated at monthly intervals to determine fruit set and fruit persistence. To evaluate maternal effects on seed pattern, representative samples of fully ripened drupes were collected from three trees of each of the four mentioned cultivars. In particular, 1.072 and 2.199 drupes were collected in 2007 and 2008 , respectively. The difference in the sample size depended on the crossing program followed in the two years and on the crosscompatibility among the olive cultivars tested.

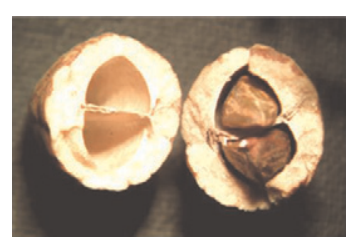

Photo 1. Double-seeded fruit in Olea europaea L. Seeds are in the endocarp.

Table 2. Contingency table $(4 \times 3)$ showing maternal effects (cultivar) on the number of normal seed per fruit (2007). ${ }^{\mathrm{z}}$

\begin{tabular}{|c|c|c|c|c|c|c|c|c|c|c|}
\hline \multirow[b]{2}{*}{ Seed pattern } & \multirow[b]{2}{*}{ Cultivar } & \multicolumn{2}{|c|}{ Ascolana Tenera } & \multicolumn{2}{|c|}{ Carolea } & \multicolumn{2}{|c|}{ Leccino } & \multicolumn{2}{|c|}{ Picholine } & \multirow[b]{2}{*}{$\begin{array}{l}\text { Percent/ } \\
\text { total seed }\end{array}$} \\
\hline & & $\begin{array}{c}\text { No. } \\
\text { of seeds }\end{array}$ & $\begin{array}{c}\text { Percent/ } \\
\text { total }\end{array}$ & $\begin{array}{c}\text { No. } \\
\text { of seeds }\end{array}$ & $\begin{array}{l}\text { Percent/ } \\
\text { total }\end{array}$ & $\begin{array}{c}\text { No. } \\
\text { of Seeds }\end{array}$ & $\begin{array}{l}\text { Percent/ } \\
\text { total }\end{array}$ & $\begin{array}{c}\text { No. } \\
\text { of seeds }\end{array}$ & $\begin{array}{l}\text { Percent } / \\
\text { total }\end{array}$ & \\
\hline \multirow{3}{*}{$\begin{array}{l}\text { Undeveloped } \\
\text { seed }\end{array}$} & Observed & 29 & 20.7 & 23 & 9.9 & 99 & 22.2 & 53 & 21.0 & 19.0 \\
\hline & Expected & 26.6 & & 44.1 & & 85.1 & & 48.1 & & \\
\hline & Cell $\chi^{2}$ & 0.2 & & 10.1 & & 2.3 & & 0.5 & & \\
\hline \multirow{3}{*}{$\begin{array}{l}\text { One normal } \\
\text { seed }\end{array}$} & Observed & 91 & 65.0 & 187 & 80.6 & 334 & 74.7 & 140 & 55.3 & 70.2 \\
\hline & Expected & 98.2 & & 162.7 & & 313.6 & & 177.5 & & \\
\hline & $\operatorname{cell} \chi^{2}$ & 0.5 & & 3.6 & & 1.3 & & 7.9 & & \\
\hline \multirow{3}{*}{$\begin{array}{c}\text { Two normal } \\
\text { seeds }\end{array}$} & Observed & 20 & 14.3 & 22 & 9.5 & 14 & 3.1 & 60 & 23.7 & 10.8 \\
\hline & Expected & 15.1 & & 25.1 & & 48.4 & & 27.4 & & \\
\hline & Cell $\chi^{2}$ & 1.6 & & 0.4 & & 24.4 & & 38.9 & & \\
\hline
\end{tabular}

${ }^{\mathrm{z}}$ Overall $\chi^{2}=91.74(* * * P \leq 0.0004)$. Underlined number: higher $\chi^{2}$ cell values.

Table 3. Contingency table $(4 \times 3)$ showing maternal effects (cultivar) on the number of normal seed per fruit (2008). ${ }^{z}$

\begin{tabular}{|c|c|c|c|c|c|c|c|c|c|c|}
\hline \multirow[b]{2}{*}{ Seed pattern } & \multirow[b]{2}{*}{ Cultivar } & \multicolumn{2}{|c|}{ Ascolana Tenera } & \multicolumn{2}{|c|}{ Carolea } & \multicolumn{2}{|c|}{ Leccino } & \multicolumn{2}{|c|}{ Picholine } & \multirow[b]{2}{*}{$\begin{array}{c}\text { Percent/ } \\
\text { total seed }\end{array}$} \\
\hline & & $\begin{array}{c}\text { No. } \\
\text { of seeds }\end{array}$ & $\begin{array}{c}\text { Percent/ } \\
\text { total }\end{array}$ & $\begin{array}{c}\text { No. } \\
\text { of seeds }\end{array}$ & $\begin{array}{c}\text { No. } \\
\text { of seeds }\end{array}$ & $\begin{array}{c}\text { No. } \\
\text { of seeds }\end{array}$ & $\begin{array}{c}\text { No. } \\
\text { of seeds }\end{array}$ & $\begin{array}{c}\text { No. } \\
\text { of seeds }\end{array}$ & $\begin{array}{c}\text { No. } \\
\text { of seeds }\end{array}$ & \\
\hline \multirow{3}{*}{$\begin{array}{l}\text { Undeveloped } \\
\text { seed }\end{array}$} & Observed & 126 & 31.9 & 38 & 11.5 & 127 & 14.2 & 142 & 24.4 & 19.7 \\
\hline & Expected & 77.8 & & 65.4 & & 175.6 & & 114.2 & & \\
\hline & Cell $\chi^{2}$ & 29.9 & & 11.5 & & 13.5 & & 6.8 & & \\
\hline \multirow{3}{*}{$\begin{array}{l}\text { One normal } \\
\text { seed }\end{array}$} & Observed & 234 & 59.2 & $2 \overline{86}$ & 86.1 & 699 & 78.4 & 393 & 67.8 & 73.3 \\
\hline & Expected & 289.6 & & 243.4 & & 653.9 & & 425.2 & & \\
\hline & Cell $\chi^{2}$ & 10.7 & & 7.5 & & 3.1 & & 2.4 & & \\
\hline $\begin{array}{l}\text { Two normal } \\
\text { seeds }\end{array}$ & Observed & 35 & 8.9 & 8 & 2.4 & 66 & 7.4 & 45 & 7.8 & 7.0 \\
\hline
\end{tabular}

${ }^{\mathrm{z}}$ Overall $\chi^{2}=97.89(P \leq 0.07)$. Underlined number: higher $\chi^{2}$ cell values. 


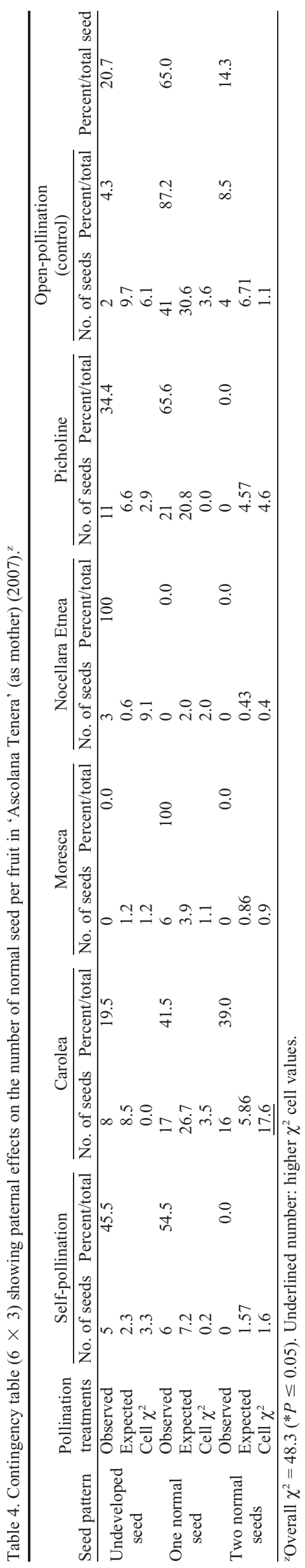

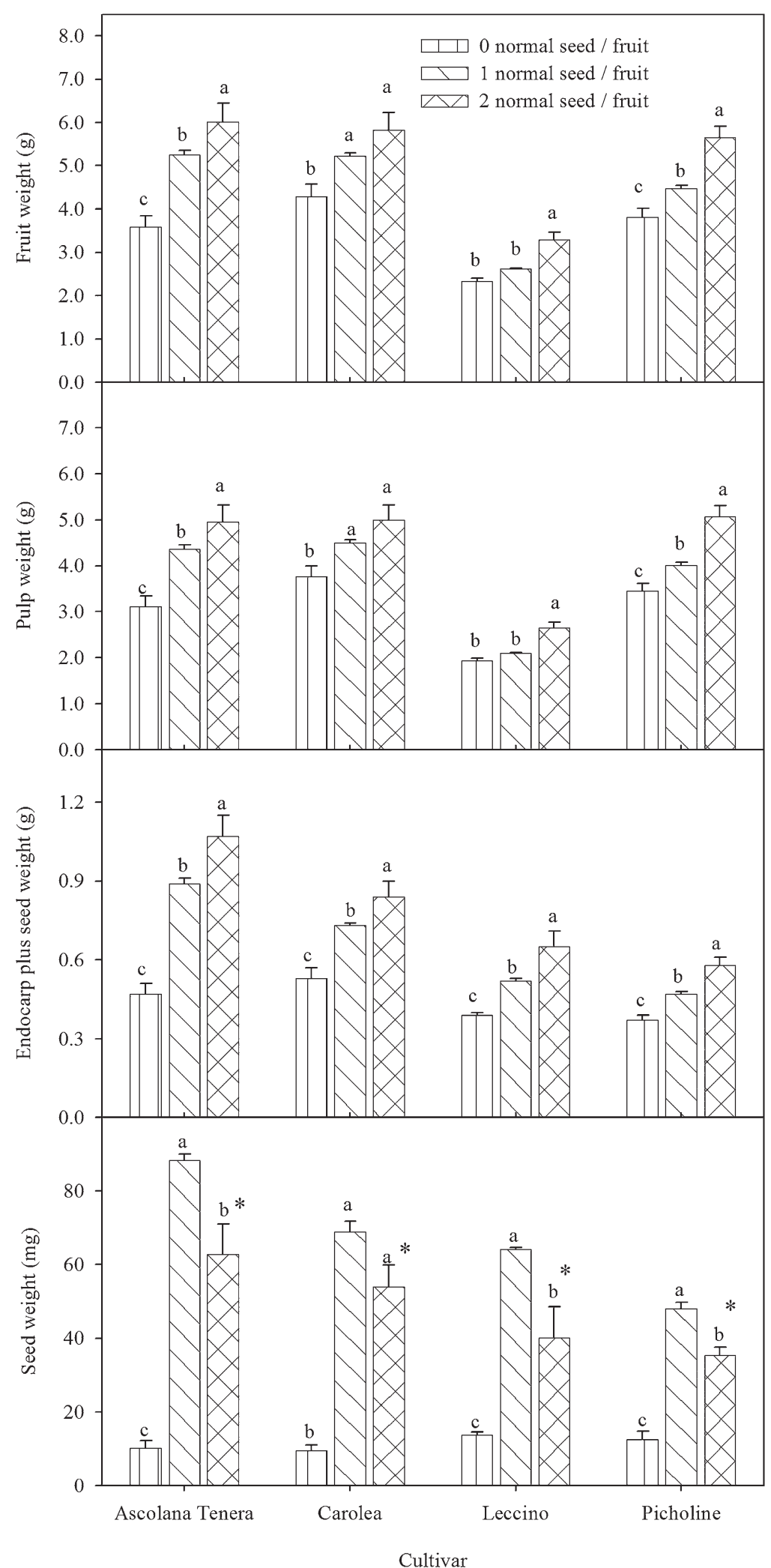

Fig. 1. Effects of seed number on fruit characteristics in 2007. For each cultivar, values followed by different letters are significantly different $(* * P<0.01)$. Results are means \pm SEs. *Single seed weight.

To elucidate the paternal effect on seed set and the impact of seed number on drupe and seed weight, drupes of the cited cultivars were classified according to the pollen source: pollen from flowers present in the experimental olive orchard (open-pollinated, control), from flowers of the same cultivar (self-pollinated), or from flowers of a selected cultivar (crosspollinated). As soon as the drupes were collected, they were weighed individually. The mesocarp was carefully removed using a seed cleaner and the 
endocarp with the seed(s) inside was weighed and then broken open to extract the seed(s). Each seed was then classified as normal or undeveloped (when not well formed) and weighed; the number of seeds per drupe (zero or one or two) was also recorded (Photo 1). The $\chi^{2}$ test of independence was used to evaluate the maternal (cultivar) and paternal (pollen) effects on the number of normal seeds per drupe. Specifically, the $\chi^{2}$ test of independence was used to test the significance of the relationship between rows (seed pattern) and columns (cultivar/pollen) in a contingency table. In each column (cultivar/ pollen), the "expected" frequencies were calculated by multiplying the total number of seeds by the percentage expected to be in the category (undeveloped seed, one normal seed, and two normal seeds) (Camussi et al., 1986).

Because the samples came from a normal distribution, the frequencies observed should be close to the expected frequencies based on a normal distribution. For each distribution, a $\chi^{2}$ test was performed to test whether the observed frequencies differed significantly from the expected frequencies. Moreover, analysis of variance [SAS Version 9.2 (SAS Institute Inc., Cary, NC)] was used to determine the influence of seed number per drupe on fresh fruit, endocarp, and seed weight and the effect of pollination treatments on drupe weight and its components. The means were compared using Duncan's test.

\section{Results}

Maternal and paternal contribution to the number of seeds. Data on seed pattern showed that in 2007 there was a significant maternal effect (cultivar) on the number of normal seeds per drupe for cultivars Leccino and Picholine, as indicated by the $\chi^{2}$ test (overall $\chi^{2}=91.74, P \leq 0.0004$ ) (Table 2). More in detail, 3.1\% of 'Leccino' and 23.7\% of 'Picholine' drupes were double-seeded with respect to $10.8 \%$ expected to be in that category (Table 2).

There was also a significant maternal effect on the number of normal seeds per drupe in 2008, as indicated by the $\chi^{2}$ test (overall $\chi^{2}=97.89, P \leq 0.07$ ) (Table 3 ). In particular, 'Ascolana Tenera' produced more drupes with undeveloped seeds $(31.9 \%$ with respect to $19.7 \%$ expected to be in that category).

On the contrary, 'Leccino' and 'Carolea' produced drupes with a lower number of undeveloped seeds $(14.2 \%$ and $11.5 \%$, respectively). Furthermore, 'Carolea' showed the lowest number of undeveloped seeds (Table 3).

Paternal effects on seed set were also proven. Crosspollination between 'Carolea', as the pollenizer, and 'Ascolana Tenera' gave rise to a higher percentage of double-seeded drupes in 2007 (overall $\chi^{2}=48.3, P \leq 0.05$ : $39 \%$ with respect to $14.3 \%$ expected to be in that category) (Table 4). Furthermore, pollen from 'Maurino' (overall $\chi^{2}=57.0, P \leq 0.08$ in 2007) and 'Ascolana Tenera' (overall $\chi^{2}=$
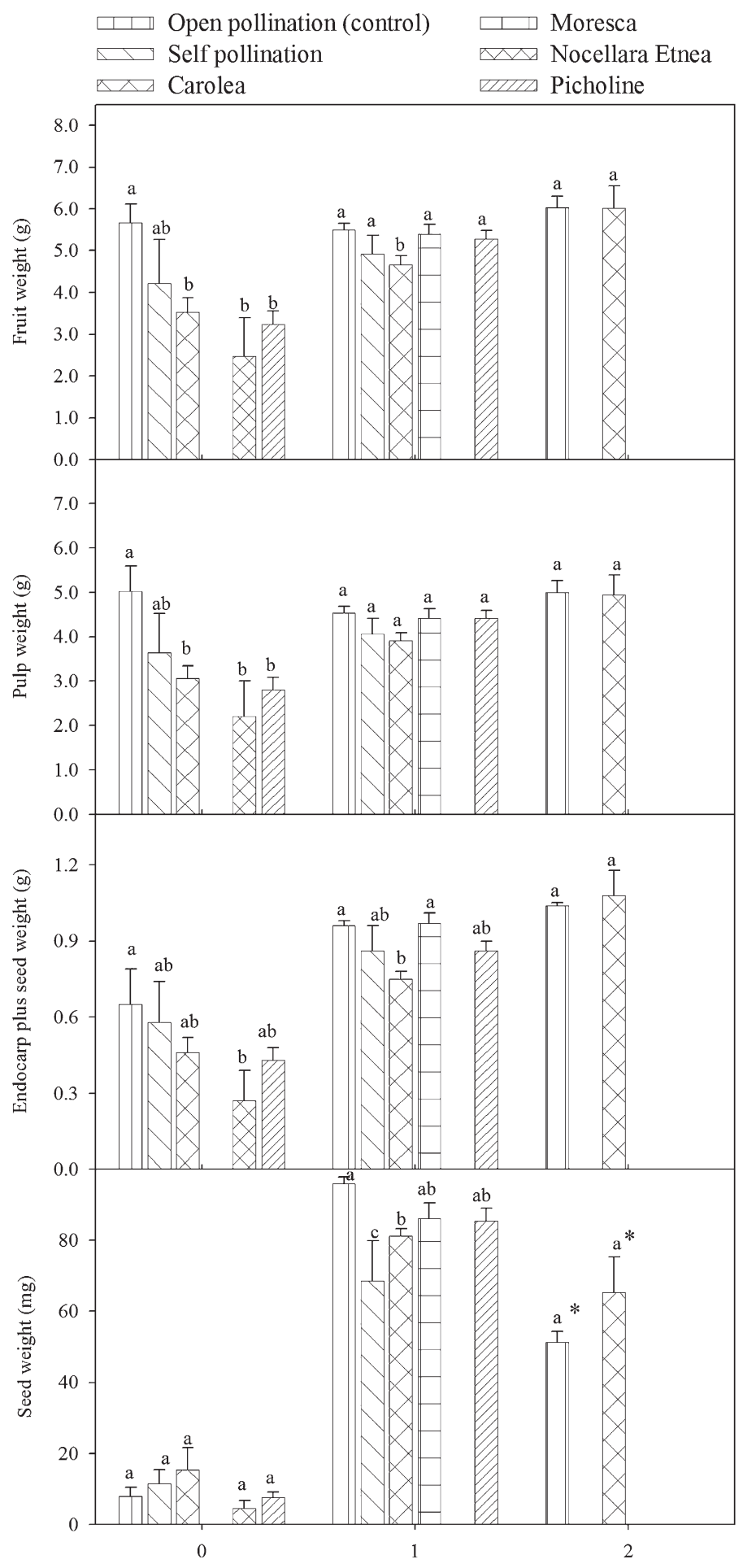

Number of seeds per fruit

Fig. 2. Effects of seed number per fruit and pollination treatments on fruit characteristics in cv. Ascolana Tenera (2007). For each seed number per fruit, values followed by different letters are significantly different $(P<0.05)$. Results are means \pm ses. *Single seed weight.

$69.9, P \leq 0.03$ in 2008) produced significant effects on 'Leccino' drupes. Specifically, in 2007, 'Maurino' as the pollenizer gave a higher number of 'Leccino' drupes with undeveloped seed ( $44.0 \%$ with respect to $22.2 \%$ expected to be in that category). Similarly, in 2008, 'Ascolana Tenera' induced a higher production of drupes with undeveloped seeds in 'Leccino', being $28.1 \%$ instead of the expected $14.2 \%$.

Effect of seed number on seed and drupe characteristics. The presence and number of normal seed influenced the fresh weight of both seeds and drupes.

In fact, in 2007, the double-seeded drupes of 'Ascolana Tenera', 'Leccino', and 'Picholine' 
were heavier than those with only one normal seed as a result of a heavier endocarp and pulp (Fig. 1).

On the contrary, 'Ascolana Tenera' and 'Picholine' drupes with undeveloped seeds were significantly lighter, whereas singleseeded drupes occupied an intermediate position (Fig. 1).

'Carolea' drupes with one or two normal seeds were similar in weight, whereas drupes with undeveloped seed were significantly lighter (Fig. 1). Concerning the effect of seed number on drupe characteristics in 2008, no significant differences were found between the weight of drupes with undeveloped seed and those with one normal seed, whereas the double-seeded drupes were always the heaviest (data not shown). Results regarding the effect of seed number per drupe and pollination treatments on drupe weight and its components are only reported for those cultivars and year for which a significant paternal effect was observed.

In 2007, pollen sources affected the weight of normal seed in 'Ascolana Tenera' drupes. In fact, with 'Carolea' pollen, the seeds were lighter compared with the openpollinated ones (Fig. 2). In the same year, the effect of seed number and the influence of pollination treatments were also observed in 'Carolea'. The weight of the drupes with one normal seed was influenced by the pollen source: pollination with 'Leccino', 'Ascolana Tenera', and 'Picholine' pollen resulted in lighter drupes than the open-pollinated ones (Fig. 3). Seed number and pollination treatments affected drupe features also in 'Leccino' in both experimental years. Particularly, in 2007, when 'Maurino' was used as the pollenizer, drupes were smaller than those obtained with 'Moresca' and 'Picholine' as pollenizers (Fig. 4); in 2008, pollination with 'Ascolana Tenera', 'Carolea', 'Kalamata', and 'Manzanilla de Sevilla' pollen resulted in the lightest drupes (data not shown).

Effect of pollination combinations on fruit set. Fruit set values determined in 2007 for 'Ascolana Tenera', 'Carolea', and 'Leccino' are reported in Figures 5 through 7, respectively.

In 'Ascolana Tenera', the best pollenizer was 'Carolea' followed by 'Picholine' (Fig. 5), whereas in 'Carolea', fruit set was higher when combined with 'Moresca' and 'Ascolana Tenera' (Fig. 6).

Although 'Carolea' was the best pollenizer for 'Leccino', satisfactory fruit set levels, comparable to the open pollination treatment, were reached by combinations with 'Maurino', 'Picholine', and 'Sorani' (Fig. 7).

\section{Discussion}

Crosspollination was necessary to achieve a satisfactory level of fruit set (Figs. 5 to 7) and drupe size in almost all the olive cultivars investigated, in particular in the selfincompatible ones such as 'Leccino'. This finding confirms what has already been shown by several researchers (Androulakis and Loupassaki, 1990; Cuevas et al., 2001; Diaz

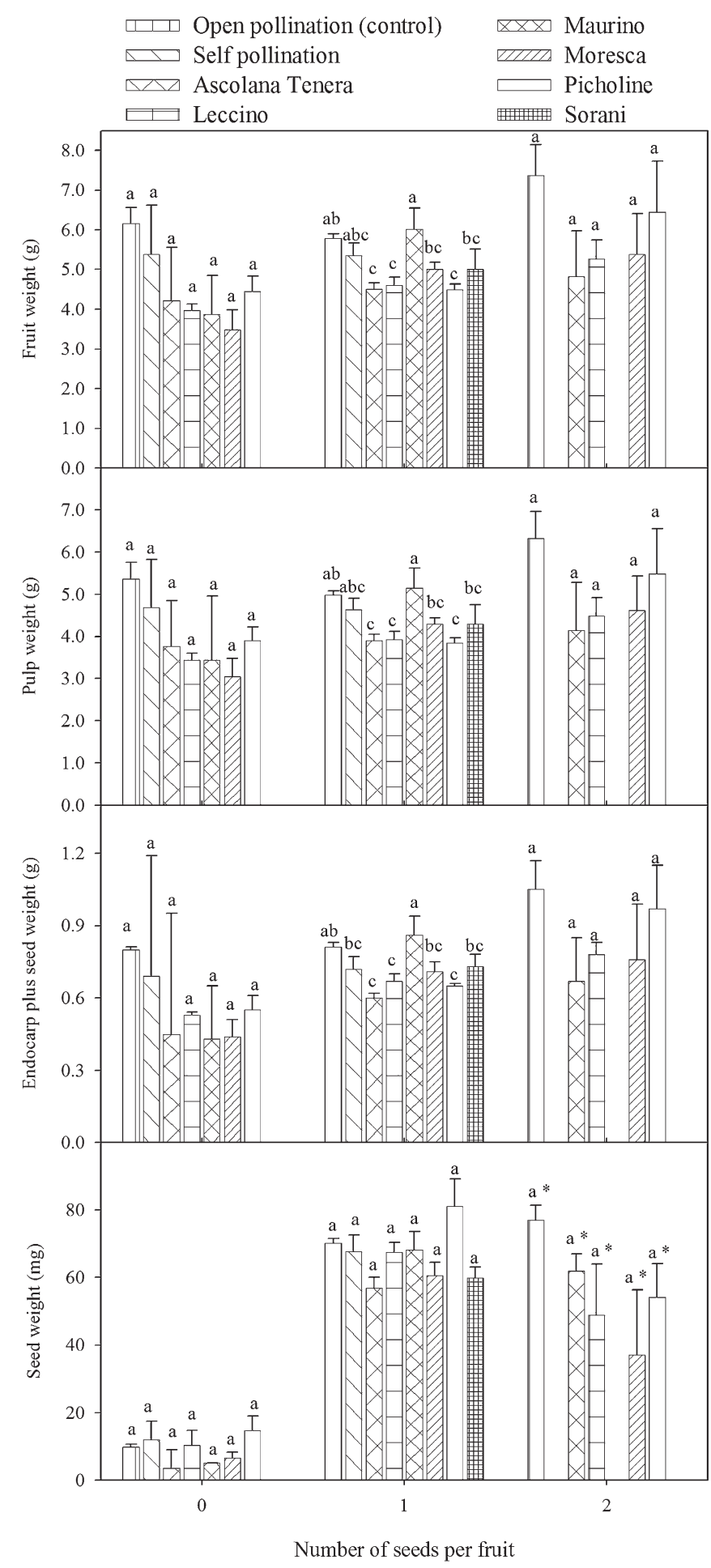

Fig. 3. Effects of seed number per fruit and pollination treatments on fruit characteristics in cv. Carolea (2007). For each seed number per fruit, values followed by different letters are significantly different $(P<0.05)$. Results are means \pm SEs. *Single seed weight.

et al., 2007; Farinelli et al., 2006; FernandezEscobar and Gomez-Valledor, 1985; Lavee and Avidana, 2011; Lavee and Datt, 1978; Mookerjee et al., 2005; Moutier, 2002; Rallo et al., 1990). The well-known pattern in olive to produce drupes containing only one seed with a closed endocarp as the dispersal unit to optimize the plant's investment in seedling survival was also confirmed in the four mother cultivars studied. In fact, $70.2 \%$ and
$73.3 \%$ of the drupes contained only one normal seed in 2007 and in 2008, respectively (Tables 2 and 3). On the other hand, double-seeded drupes occur in common singleseeded species and deviations from this general pattern are of great ecological interest (Auspurger, 1986; King, 1938; Lee, 1988). In olive, this has important agronomic consequences because drupe growth and oil content are positively related to drupe weight 


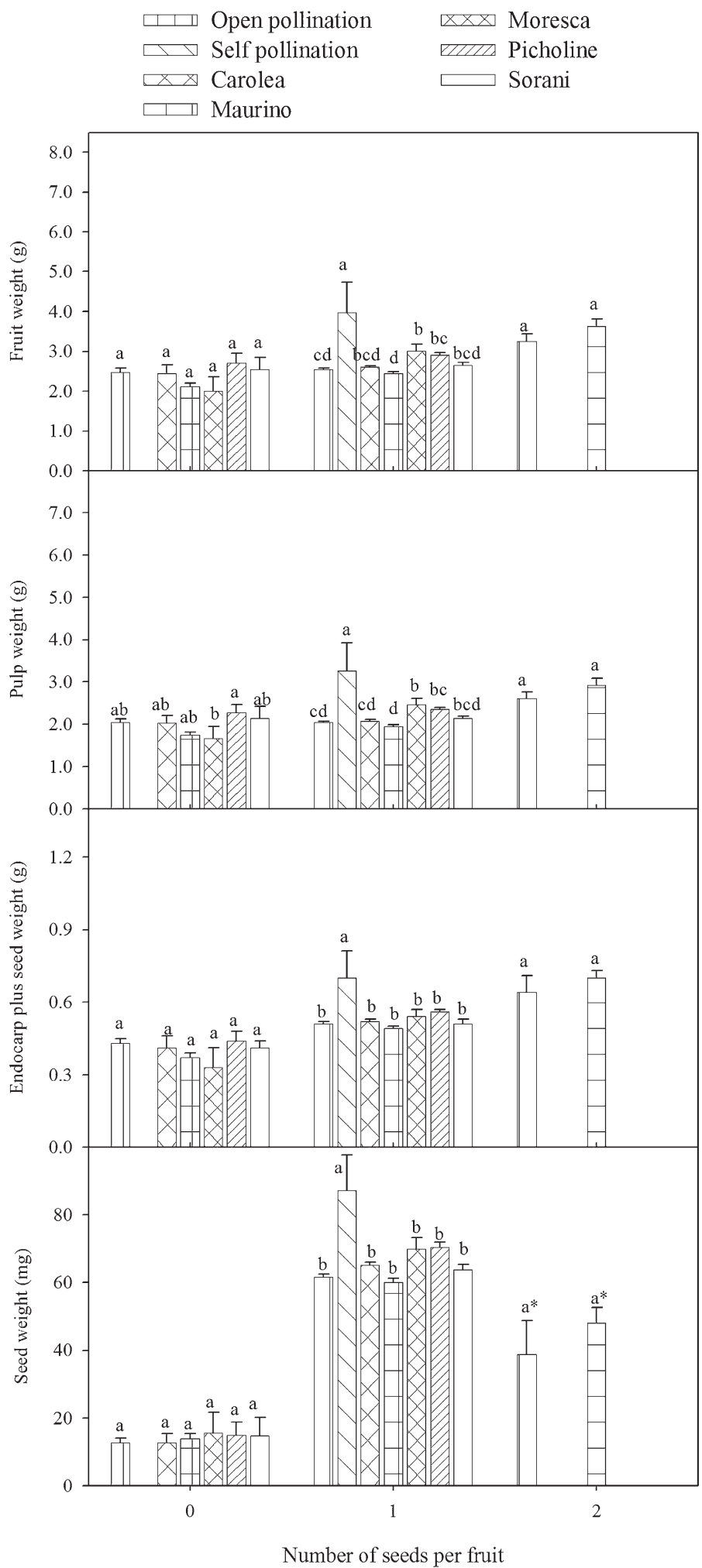

Fig. 4. Effects of seed number per fruit and pollination treatments on fruit characteristics in cv. Leccino (2007). For each seed number per fruit, values followed by different letters are significantly different $\left({ }^{*} P<0.05\right)$. Results are means \pm SEs. *Single seed weight.

and seed number (Cuevas and Oller, 2002; Farinelli et al., 2002b, 2008b). Maternal effects on seed pattern and its influence on drupe weight have been proven for doubleseeded drupes (Auspurger, 1986; Lee, 1988; Roy and Kochba, 1974). The present study pointed out that the number of normal seeds affected seed and drupe fresh weight. In fact, in 2007, the double-seeded drupes of 'Ascolana Tenera', 'Leccino', and 'Picholine' were heavier than those with only one normal seed as a result of heavier endocarp and pulp (Fig. 1). In particular, this study confirms that the phenomenon of double-seeding in olive could be cultivar-dependent, as already observed in Hojiblanca (Cuevas and Oller, 2002), with 'Picholine' producing the most double-seeded drupes (23.7\%). However, far from being a problem, drupes with two normal seeds have been found to be heavier and larger, which makes them suitable for table olives. Although the total resources allocated to seed development were higher in drupes with two normal seeds, each seed from double-seeded drupes weighed slightly less than those from single-seeded drupes (Figs. 1 to 3). It has been reported that the common production of drupes with undeveloped seed also affects drupe weight: drupes without normal seed were generally lighter than those with normal seed, as already noted in 'Sevillano' (Cuevas and Oller, 2002). In our experiment, it was observed that 'Ascolana Tenera', 'Carolea', and 'Picholine' drupes without normal seed were significantly smaller in 2007 (Fig. 1). On the other hand, no significant differences were recorded in 2008. In this regard, in 2008 in 'Ascolana Tenera', although the percentage of drupes without normal seed was significantly higher (up to $31.9 \%$ ) (Table 3), this did not affect their final weight, which was not different from those with one normal seed ( $3.15 \mathrm{~g}$ vs. $3.27 \mathrm{~g})$. This has a practical advantage because 'Ascolana Tenera' is a table-purpose variety. More remarkably, the source of pollen used for pollination also affected the number of seeds. Although a higher percentage of double-seeded drupes was found in 'Ascolana Tenera' with 'Carolea' pollen (Table 4), in 'Carolea' with 'Leccino' pollen and in 'Leccino' with 'Ascolana Tenera' and 'Maurino' pollen, there was a significant increase in the percentage of undeveloped seeds. In this last combination ('Leccino' $X$ 'Maurino'), the increase in 'Leccino' drupes with undeveloped seed was very significant (up to $44.0 \%$ ). Such finding has a practical consequence because the Maurino cultivar was one of the best pollenizers of 'Leccino' flowers, giving a fruit set that did not differ from that of the control (open-pollinated flowers) (Fig. 7). The paternal effect of 'Ascolana Tenera' (increasing the number of drupes with undeveloped seeds up to $28.1 \%$ ) on 'Leccino' seed characteristics was also significant, considering that as a pollenizer, this cultivar increased the number of fruit per inflorescence (Farinelli et al., 2008a). On the other hand, the weight of 'Leccino' drupes with undeveloped seed was not significantly different from those with one normal seed in both experimental years, suggesting that in this variety, seed death occurs late. In fact, the final weight of drupes with undeveloped seed also depends on the precocity with which seed death occurs. If the seed dies at a later stage of fruit development, its death might not significantly affect the final size (Lavee, 1996, 2006; Rallo et al., 1981; Rapoport, 1994).

\section{Conclusions}

The findings of this study could be very useful for olive sector operators (nurserymen, olive farmers, technicians), helping them to 


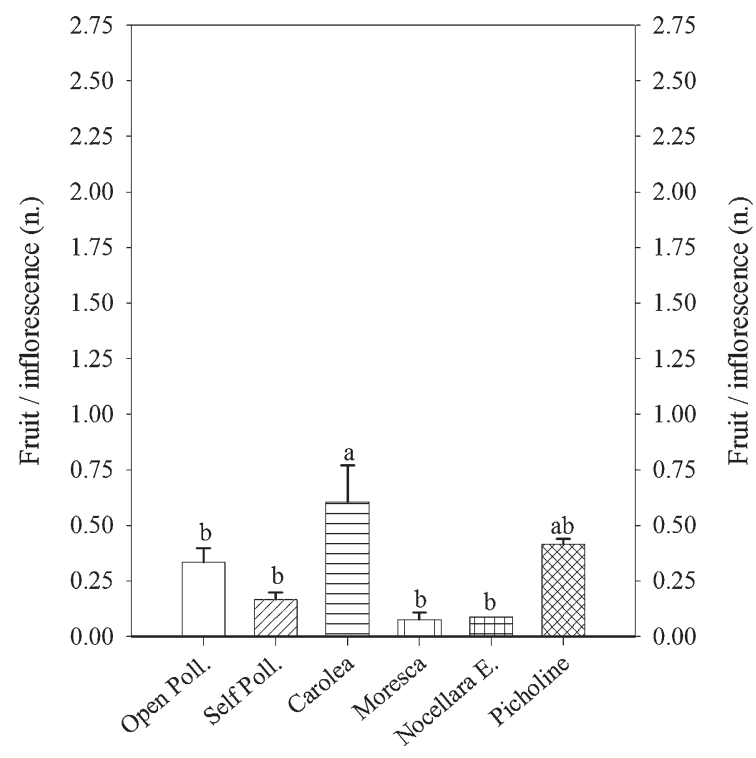

Fig. 5. Pollination response of cv. Ascolana Tenera in 2007, expressed as number of fruit per inflorescence determined 21 days after full bloom (means \pm SEs followed by the same letter are not significantly different at $* P<0.05$ ).

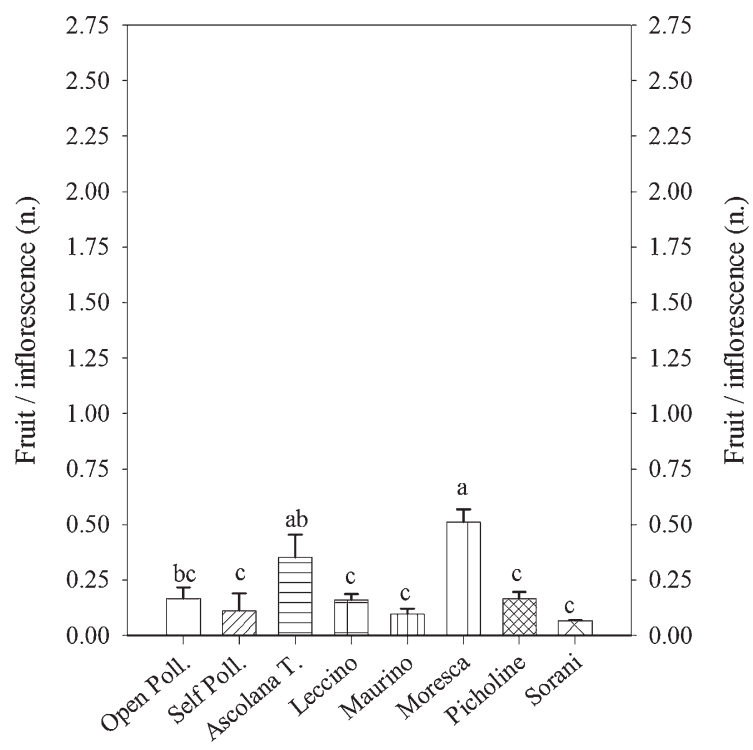

Fig. 6. Pollination response of cv. Carolea in 2007, expressed as number of fruit per inflorescence determined 21 days after full bloom (means \pm SES followed by the same letter are not significantly different at $* P<0.05$ ).

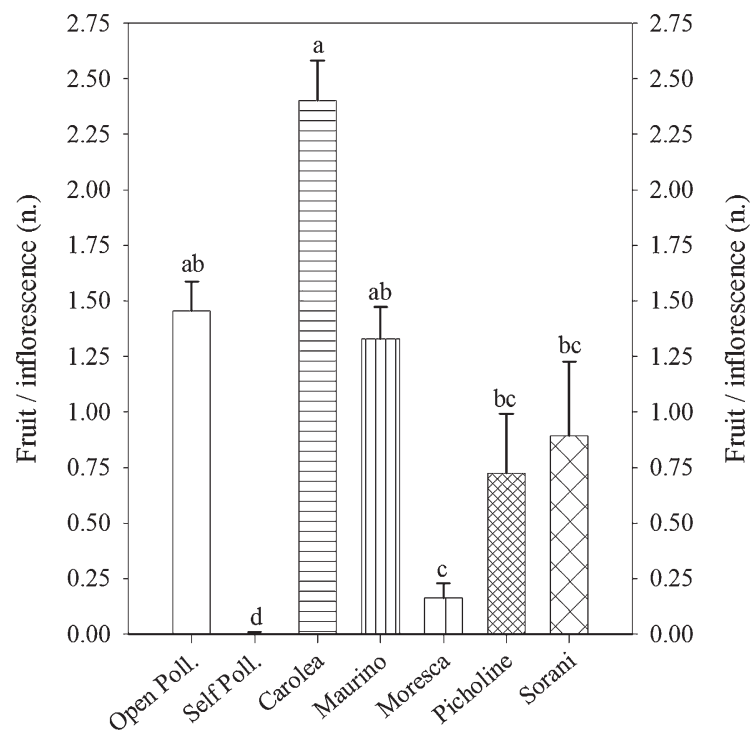

Fig. 7. Pollination response of cv. Leccino in 2007, expressed as number of fruit per inflorescence determined 21 days after full bloom (means \pm SES followed by the same letter are not significantly different at $* P<0.05$ ). 
plan profitable production strategies. Particularly, closer attention should be given to the best cultivar/pollenizer combinations to maximize olive production in terms of drupe number and weight and fruit uniformity, especially in case of table-purpose olive varieties. According to our results, crosspollination combinations between 'Picholine', as a pollenizer, and 'Ascolana Tenera' were the most efficient in term of normal seed as well as those among 'Carolea', 'Picholine', 'Kalamata', and 'Manzanilla de Sevilla' as pollenizers and 'Leccino'. Instead, the combination between 'Carolea', as a pollenizer, and 'Ascolana Tenera' showed the highest presence of double-seeded drupes and the best fruit characteristics.

\section{Literature Cited}

Androulakis, I.I. and M.H. Loupassaki. 1990. Studies on self-fertility of some olive cultivars in the area of Crete. Acta Hort. 286:159-162.

Auspurger, C.K. 1986. Double and single-seeded in indehiscent legumes of Platypodium elegans: Consequences for wind dispersal and seedling growth and survival. Biotropica 18:45-50.

Bartolini, G. 2012. OLEA databases. <http://www. oleadb.it $>$.

Camposeo, S., G. Ferrara, M. Palasciano, and A. Godini. 2012. About the biological behaviour of cultivar 'Coratina'. Acta Hort. (ISHS) 949: 129-133.

Camussi, A., F. Möller, E. Ottaviano, and M. Sari Gorla. 1986. Metodo del test $\chi^{2}$. In: Zanichelli (ed.). Metodi statistici per la sperimentazione biologica.

Cuevas, J., A.J. Diaz-Hermoso, D. Galian, J.J. Hueso, V.P.M. Pinillos, D. Sola, and V.S. Polito. 2001. Response to cross pollination and choice of pollinisers for the olive cultivars (Olea europaea L.) 'Manzanilla de Sevilla', 'Hojiblanca' and 'Picual'. Olivae 85:26-32.

Cuevas, J. and R. Oller. 2002. Olive seed set and its impact on seed and fruit weight. Proc. $4^{\text {th }}$ Intl. Symp. on Olive Growing. Valenzano (Bari) Italy, 25-30 Sept. 2000. Acta Hort. 586:485-488.

Cuevas, J., L. Rallo, and H.F. Rapoport. 1995. Procedure to study ovule senescence in olive. Sci. Hort. 59:123-130.

Diaz, A., A. Martin, P. Rallo, and R. Rosa de la. 2007. Cross-compatibility of the parents as the main factor for successful olive breeding crosses. J. Amer. Soc. Hort. Sci. 132:830-835.

Farinelli, D., M. Boco, and A. Tombesi. 2006. Results of four years of observations on selfsterility behaviour of several olive cultivars and significance of cross-pollination. Proc. Second Intl. Seminar on "Biotechnology and quality of olive tree products around the Mediterranean
Basin-Olivebioteq 2006," 5-10 Nov. 2006, Marsala, Mazara del Vallo, Italy. Vol. I. p. 275-282.

Farinelli, D., D. Hassani, C. Grandoni, M. Boco, and A. Tombesi. 2002a. Impollinazione incrociata nelle varietà di olivo. Rivista di Frutticoltura e di ortofloricoltura, Speciale olivo vol. LXIV, n. 10. p. 77-81.

Farinelli, D., D. Hassani, M. Pilli, and A. Tombesi. 2002b. Caratteristiche dei frutti in funzione dell'impollinatore impiegato. Rivista di Frutticoltura e di Ortofloricoltura LXIV:83-87.

Farinelli, D., D. Hassani, and A. Tombesi. 2008a. Self-sterility and cross-pollination responses of nine olive cultivars in central Italy. Acta Hort. 791:127-136.

Farinelli, D., D. Hassani, and A. Tombesi. 2008b. Paternal and maternal effects on seed characteristics of olive cultivars. Acta Hort. 791: 121-125.

Fernandez-Escobar, R. and G. Gomez-Valledor. 1985. Cross-pollination in "Gordal Sevillana" olives. HortScience 20:191-192.

Ferrara, G., S. Camposeo, M. Palasciano, and A. Godini. 2007. Production of total and stainable pollen grains in Olea europaea L. Grana 46:85-90.

Guerin, J. and M. Sedgley. 2007. Cross-pollination in olive cultivars. RIRDC Pubblication No. 07/169.

Grossman, Y.L. and T.M. DeJong. 1994. Peach: A simulation model of reproductive and vegetative growth in peach trees. Tree Physiol. 14:329-345.

Grossman, Y.L. and T.M. DeJong. 1995. Maximum fruit growth potential following resource limitation during peach growth. Ann. Bot. (Lond.) 75:561-567.

King, J.R. 1938. Morphological development of fruit of the olive. Hilgardia 11:437-453.

Koubouris, G.C., I.T. Metzidakis, and M.D. Vasilakakis. 2010. Influence of cross-pollination on the development of parthenocarpic olive (Olea europaea) fruits (shotberries). Exp. Agr. 46:67-76.

Lavee, S. 1996. Biology and physiology of the olive. In: World olive encyclopaedia. International Olive Oil Council. p. 71-96.

Lavee, S. 1998. Pollination and cross pollination requirements of olive cultivars. The Tree Cropper 13:14-15.

Lavee, S. 2006. Biennal bearing in olive (Olea europaea L.). Olea 25:5-13.

Lavee, S. and B. Avidana. 2011. Heredity diversity in populations of free- self-, and cross-pollinated progenies of some olive (Olea europaea L.) cultivars. Isr. J. Plant Sci. 59:29-37.

Lavee, S.Z. and Z. Datt. 1978. The necessity of cross-pollination for fruit set of Manzanillo olives. J. Hort. Sci. 53:261-266.

Lee, T.D. 1988. Pattern of fruit and seed production, p. 179-201. In: Lovett-Doust, J. and L. Lovett-Doust (eds.). Plant reproductive ecology. Patterns and strategies. Oxford Univ. Press. New York, NY.
Marcelis, L.F.M. and E. Heuvelink. 1999. Modelling fruit set, fruit growth and dry matter partitioning. Acta Hort. 499:39-49.

Martin, C.M., L. Ferguson, and G.S. Sibbet 2005. Flowering, pollination, fruiting, alternate bearing and abscission, p. 49-54. In: Olive production manual. University of California, Agriculture and Natural Resources, Publication 3353 .

Martin, C.M. and G.S. Sibbett. 2005. Botany of olive, p. 15-17. In: Olive production manual. University of California, Agriculture and Natural Resources. Publication 3353.

Mookerjee, S., J. Guerin, G. Collins, C. Ford, and M. Sedgley. 2005. Paternity analysis using microsatellite markers to identify pollen donors in an olive grove. Theor. Appl. Genet. 111:1174-1182.

Morettini, A. 1950. Biologia fiorale della fruttificazione. In: Ramo Editoriale degli Agricoltori Roma (eds.). Trattati di Agricoltura. Vol. 9. Olivicoltura. p. 129-136.

Moutier, N. 2002. Self-fertility and intercompatibilities of sixteen olive varieties. In: Fourth Intl. Symp. on Olive Growing. Intl. Soc. Hort. Sci., Bari, Italy. p. 209-211.

Rallo, L., J. Cuevas, and H.F. Rapoport. 1990. Fruit set pattern in self and open-pollinated cultivars. Acta Hort. 286:219-222.

Rallo, L., G.C. Martin, and S. Lavee. 1981. Relationship between undeveloped embryo sac development and fruitfulness in olive. J. Amer. Soc. Hort. Sci. 106:813-817.

Rapoport, H.F. 1994. The timing and developmental context of olive embryo growth. Acta Hort. 356:268-271.

Rapoport, H.F. and L. Rallo. 1990. Ovule development in normal and parthenocarpic olive fruits. Acta Hort. 286:223-226.

Rodriguez-Castillo, E., A. Diaz, A. Belaj, and R. Rosa de la. 2009. Inter-compatibility relationships in olive as revealed by paternity tests with SSR markers. Acta Hort. 814:659-662.

Rosa de la, R., C.M. James, and K.R. Tobutt. 2004 Using microsatellites for paternity testing in olive progenies. HortScience 39:351-354.

Rosati, A., M. Zipanćič, S. Caporali, and A. Paoletti. 2010. Fruit set is inversely related to flower and fruit weight in olive (Olea europaea L.). Sci. Hort. 126:200-204.

Roy, S.P. and J. Kochba. 1974. The inheritance of bitter and double kernel characters in the almond (Prunus amygdalus Bastsch). Z. P. flanzenzeuechtg. 71:319-329.

Stafford, L.M. 1970. Effect of pollinators on fruit set, fruit weight and seed numbers of Early Imperial and Ellendal mandarins. Aust. J. Exp. Agr. Anim. Husb. 10:644-646.

Tombesi, A., A. Cartechini, and P. Preziosi. 1982. La interfertilità fra le cultivar di olivo, Frantoio, Leccino, Maurino e Moraiolo. Annali della Facoltà di Agraria. Università degli Studi di Perugia XXXVI:345-356. 